\title{
Assessing the impact and antecedents of university scientific research on firms' innovation commercialisation
}

\section{Luca Dezi}

University of Naples 'Parthenope',

Via Generale Parisi, 13, 80132 Napoli, Italy

Email: luca.dezi@uniparthenope.it

*Corresponding author

\section{Gabriele Santoro}

Department of Management, University of Turin,

Corso Unione Sovietica 218/bis, 10134 Torino, Italy

Email: gabriele.santoro@unito.it

\section{Filippo Monge}

Department of Economics and Statistics, 'S.Cognetti de Martiis',

University of Torino, Lungo Dora Siena, 100 A, 10153 Torino, Italy

Email: filippo.monge@unito.it

\section{Yue Zhao}

Paris School of Business, 59 Rue Nationale, 75013 Paris, France

Email: y.zhao@psbedu.paris

\begin{abstract}
University-firm links have stimulated a lot of attention. In fact, with the increasing knowledge and technologies created within university laboratories, firms have identified business opportunities by accessing the knowledge developed by external actors and commercialising universities' inventions. In this case, they adopt a knowledge acquisition strategy to foster innovation, reducing risk and exploiting new technological opportunities. This underlines a shift in the role of universities from education providers to scientific knowledge and technologies producers in the current knowledge-driven economy. In this context, the main goal of this paper is to assess the impact of knowledge acquisition on firms' innovation commercialisation, with a specific focus on knowledge developed by university scientific research. By applying hierarchical regressions on a sample of
\end{abstract}


185 Italian knowledge-intensive firms (KIFs), the findings indicate that firms benefit from research partnerships with and services from universities, when they also seek knowledge from other counterparts and when they possess higher levels of internal absorptive capacity.

Keywords: university-firm collaborations; knowledge acquisition; open innovation; knowledge-intensive firms; KIFs; university scientific research.

Reference to this paper should be made as follows: Dezi, L., Santoro, G., Monge, F. and Zhao, Y. (2018) 'Assessing the impact and antecedents of university scientific research on firms' innovation commercialisation', Int. J. Technology Management, Vol. 78, Nos. 1/2, pp.88-106.

Biographical notes: Luca Dezi is a Full Professor of Economics and Management of Companies at the University 'Parthenope', Faculty of Economics, Naples. He is in scientific field/SECS - P08, Economy and Company Management. $\mathrm{He}$ is a Professor of Strategic Marketing and International Business at the Faculty of Communication Sciences, Department CO.RI.S., University of Studies of Rome, Sapienza University. He is a member of the Company's Board of Auditors San Giovanni Addolorata Hospital in Rome from 2007 to 2011 and ordinary member of the Italian Academy of Business Economics. He is a Chartered Accountant and Auditor. He is a consultant in the field of economic and financial analysis, planning and management control, evaluation of businesses and projects, corporate restructuring, mediations, rationalisation and resource management, teaching and training on behalf of medium-sized and large companies, public institutions and organisations.

Gabriele Santoro is a Post-doc Researcher in Business and Management at the Department of Management, University of Torino. His main areas of research include open innovation, knowledge management, social innovation and alliances in smart cities. His works have been published in international academic journals such as Journal of Technology Transfer and Journal of Knowledge Management. Dr Santoro's research entitled Users Generated Ideas via Social Media Networks (SMNs): Based on Open Innovation Model was awarded as Best Paper award of the EuroMed $\backslash$ SIMA track 'New challenges in open innovation' at the 9th annual EuroMed Academy of Business (EMAB) Conference (2016).

Filippo Monge graduated in Business Economics at the University of Torino and he completed his studies at LSE. In 1996, he started as a Lecturer at the SAA School of Management of University of Torino. Since 1995, he served on the boards of directors of private and public companies and organisations. Since 2006, he is an Adjunct Professor (Tenure) of Marketing and BA form the University of Torino. From 2010 to 2012, he was a member of National Council for Economy and Labour (government). His research activities focused on tourism, real estate and construction, banking, non-profit sector and innovation.

Yue Zhao holds a PhD in Business Administration from the ESSEC Business School, and is an Associate Professor at the PSB Paris School of Business. Her research interests include creative industries (such as mobility of fashion designers, spatial staging of artworks in museums, and collaboration between perfumery and gastronomy), history and sociology of fashion, field transformation, network analysis, and institutional theory. She also teaches and publishes in luxury management. 


\section{Introduction}

Management scholars and managers have drawn attention to the increasing adoption of collaborative and networked innovation models (Chesbrough, 2006; Díaz-Díaz and de Saá Pérez, 2014; Chesbrough et al., 2006). Rather than just exploiting internal R\&D, organisations increasingly engage in open innovation modes by integrating both intra and extra sources of knowledge. This means that innovation encompasses distributed interorganisational networks and ecosystems involving public and private actors rather than a single firm (Chandler, 1990). Therefore, the burgeoning of an open, networked and dynamic innovation model has been proposed to explain the nonlinear, iterative and interorganisational features of innovation (Van de Vrande et al., 2010; Bresciani et al., 2016).

Many of these connections are developed and maintained as formally established interorganisational agreements, such as R\&D alliances (Hagedoorn et al., 2000; Sampson, 2007; Bresciani et al., 2015) or innovation collaboration with value chain entities (West and Bogers, 2014; Santoro et al., 2016). Others result from informal ties among members of different organisations (Gulati, 1998; Enkel, 2010; Bresciani et al., 2017; Campanella et al., 2017).

Among all these interorganisational links, the one between universities and firms has specific hallmarks and processes, and has stimulated a lot of attention (Anselin et al., 1997; Arvanitis et al., 2005; Cunningham and Link, 2015). Accordingly, universities' research activities and the scientific knowledge generated have been considered as a source of socio-economic development (Autio and Laamanen, 1995; Isaksen and Karlsen, 2010).

New open, networked and interactive innovation models highlight that actual relationships between universities and industry play a decisive part in generating innovative ideas (Link et al., 2003; Segarra-Blasco and Arauzo-Carod, 2008; Enkel et al., 2009). In fact, many industries' technology development has benefited from publicly funded research performed in university laboratories (Isaksen and Karlsen, 2010; Myoken, 2010; Salter and Martin, 2001). In general, the knowledge transfer from university to firms is affected by several factors, such as the appropriability regime and the nature of the knowledge (Fontana et al., 2006). Moreover, firms should develop specific internal capabilities acting to identify and exploit such knowledge properly (Teece, 1986).

University-industry ties and the specific aspect of their impact on innovation has been an enduring object of analysis in several fields in management studies (Meyer-Krahmer and Schmoch, 1998; Carayannis and Laget, 2004; Medda et al., 2005). In addition, policy makers have been interested in this topic as they have pushed for initiatives and specific measures aimed at promoting research across disciplines and fields. The weight of specific public-private research partnerships has increased to date, indicating that by leveraging different assets and competencies, new technological breakthroughs can be achieved (Carayannis, 1998; Scuotto et al., 2016).

Other factors underline the impact of knowledge generated by universities - for example, the diffusion of technology transfer offices within university structures and the increasing propensity to license knowledge and technology to firms (Segarra-Blasco and Arauzo-Carod, 2008; Calza et al., 2014). 
In turn, university researchers do not generally possess the complementary assets necessary to bring the early-stage research results into a commercialised product (Fabrizio, 2007; Santoro et al., 2016).

This work aims at assessing the role of university scientific research on firms' innovation commercialisation. To reach this goal, we employ a quantitative methodology involving hierarchical regression models on a sample of 185 Italian knowledge-intensive firms (KIFs). First, we contribute to literature highlighting two different collaboration modes with universities, namely university research partnerships (URP) and university research services (URS), given that the impact on firm's innovation commercialisation could be different. Second, previous works on the relationship between university and firm research have focused on patent as measure of innovation. However, sometimes patents do not describe the innovativeness of a firm; therefore, we decided to use a survey methodology through a structured questionnaire to gather data. In this way, we evaluate the strategic role of universities as partners for pursuing innovation. Nonetheless, partnerships with universities in most cases are not sufficient for developing innovation. For this reason, we anticipate that firms engaged in knowledge acquisition strategies (Laursen and Salter, 2006) and with higher absorptive capacity (Hayton and Zahra, 2005) are expected more to exploit university knowledge.

Following this introduction, the next section reviews the literature on university-industry collaborations. Then, the hypotheses and the consequent model are illustrated. Section 4 describes the methodology before the Section 5 shows the main results of the paper. The final section debates the results and presents implications, limitations and future lines of research.

\section{Theoretical framework}

There is growing agreement upon the role of external sources of knowledge within innovation management literature (Caloghirou et al., 2004; Chesbrough, 2006; Del Giudice and Della Peruta, 2016). Firms coping with the dynamic and changing environment characterised by rising costs of R\&D and shortening of product lifecycles have to adapt with flexibility and responsiveness (Dezi, 1996a). As a result, firms are increasingly developing boundary-spanning ties for knowledge creation by exploring external sources and engaging in various collaborative modes (Beije and Dittrich, 2008; Kim and Park, 2010; Santoro et al., 2016).

In this vein, although the sources of innovation and the ability of a firm to collaborate with partners differ between firms and industries, the open innovation literature suggests the benefits of collaborating in any forms with both market-based sources and science-based sources for a wide range of firms and industries (Bianchi et al., 2011; Vrontis et al., 2017). In such a context, there is abundant evidence that knowledge sharing between industry and university occurs through different paths (Fabrizio, 2006; Romano et al., 2014). However, even though empirical works highlight that innovation processes can benefit from diverse collaboration (Dezi, 1996b), how to develop and coordinate effective collaboration between diverse actors is a somewhat unexplored field.

Thus, universities are modifying their traditional roles of education and research production with the aim of generating and disseminating knowledge to foster growth (Romano et al., 2014). Moreover, the commercialisation of university knowledge has 
grown noticeably due to patenting and joint ventures. By joining these networks, universities capture value from their investments and their research activities, in turn contributing to economic and societal growth (Han and Heshmati, 2016). Firms can reduce time-to-market and exploit new technological opportunities through lower research and development costs (Chesbrough and Prencipe, 2008). Prior research points out that disruptive innovation often come from fields' intersection (Johansson, 2004; Del Giudice and Maggioni, 2014) and from knowledge combination, when innovators are able to connect ideas and fields that seem unrelated (Enkel and Gassmann, 2010). Nevertheless, even though recent studies have emphasised external sources for improving innovativeness in the context of university-industry relationships, their dynamics are rather unexplored.

Two factors among others explain the weight of university-industry ties in the current scenario: the increasing number of measures and laws on intellectual property, the burgeoning of science parks and technology transfer offices, and the growing patenting activity of university researchers, which have promoted the intensifying of business-research models.

The traditional open science environment of university research makes this transfer of knowledge different from transfer between two profit-seeking firms, since university researchers have different incentives compared with a firm that has generated an innovation or technology. For example, researchers of universities look for reputation rewards and therefore often they are pushed to protect their intellectual contributions. In fact, they openly publish and distribute their contributions for career expectations or for personal gratification. Therefore, under the traditional stance of university researchers, a lack of property rights does not create a desire for secrecy and inhibit knowledge transfer.

However, there are numerous barriers to the effective transfer of knowledge and technologies from universities to firms, such as culture differences and ineffective management of the collaboration (Siegel et al., 2003).

In order to investigate the university-firm relationship, our paper is underpinned by two main types of tie, adapted from Perkmann and Walsh (2007): URP and URS. The former concerns specific formal partnerships such as R\&D projects, collaborative research activities, also known as sponsored research, and firm-university research centres. Research services are provided by academic researchers following the needs of industrial clients.

\section{The research model and hypotheses}

In general, the extensive literature on the university-industry relationship underlines the positive impact of scientific results on economic growth. Earlier studies indicate that industrial patents heavily cite university-generated published basic research, and that there is an increasing weight of university and firm cross-citations (Narin et al., 1997).

Furthermore, literature traces that without universities' research findings, many innovations would not exist or would have been established later (Beise and Stahl, 1999), and scientific research production sustains the research productivity and patenting activity of firms (Cohen et al., 1998). The literature investigates the contribution of university knowledge to both firms' idea generation and innovation development, indicating that, although in both phases the knowledge provided by actors such as customers and suppliers is more important, the contribution of universities is relevant 
(Fontana et al., 2003). This is particularly true when the knowledge is shared through publications and conference participations (Cohen et al., 2002).

Most of the studies that are based on direct measures of knowledge transfer - primarily R\&D cooperation and/or intensive use of university knowledge as an external knowledge source - indicate that the higher the knowledge from the university, the higher the firm's innovation performance in terms of propensity to register patents, number of patent applications, R\&D intensity, and introduction of product and/or process innovations (Bloedon and Stokes, 1994; Santoro and Chakrabarti, 2002).

Moreover, collaborations with scientific actors increase firms' abilities to develop and commercialise radical innovation (Kaufmann and Tödtling, 2001). Furthermore, a study based on pooled data from European firms found that the probability of engaging with research institutions is not correlated with R\&D intensity, but is associated with patents (Mohnen and Hoareau, 2003).

Others suggest that firms are more proactive in sourcing and acquiring knowledge from universities when they possess high R\&D intensity (Arvanitis et al., 2008). In line with this, in assessing the impact of university research on firms' economic performance, many studies have reported positive effects on labour productivity and sales from innovative products (Belderbos et al., 2004; Branstetter and Ogura, 2005).

Firms collaborating with university scientists therefore generate more important patents (Cockburn and Henderson, 1998) and patents are a direct measure of a firm's innovativeness (Katila and Ahuja, 2002). Summarising, the productivity of business $R \& D$ increases with university participation in the R\&D process (Link and Rees, 1990), and if a university seeks to act as a complement to private sector collaborative R\&D, it needs to structure its program according the demand side (Leyden and Link, 2013). Other specific benefits of collaborating with universities are in regard to access to university research and discoveries, leveraging research investments and sharing of R\&D expenditure (Lee, 2000).

Taken together, the results of these studies confirm that both URP and URS exert positive effects on firms' innovation commercialisation.

H1 URP exerts a positive effect on firms' innovation commercialisation.

H2 URS exerts a positive effect on firms' innovation commercialisation.

Literature indicates that some kinds of firm are more able to collaborate with and sourcing knowledge from universities. Firstly, some studies point out that firms investing heavily in R\&D are likely to possess high technological capabilities, which in turn allow absorption of external knowledge (Bercovitz and Feldman, 2007). In fact, the absorptive capacity concept indicates that the higher the firm's R\&D intensity, the higher the probability of a profitable relationship with external actors and the greater the number of collaborative R\&D projects (Cohen and Levinthal, 1990; Van Den Bosch et al., 1999; Zahra and George, 2002). The aptitude to assimilate such results requires even more expertise, and may also require interaction with university scientists in order to fully understand and exploit those results. In addition, active collaboration between university and firm researchers may facilitate more complete and quick knowledge sharing (Tidd and Trewhella, 1997; Del Giudice et al., 2013). A wider knowledge base enables a more effective search for innovative combinations by firm R\&D employees (Cockburn et al., 2000; Ahn et al., 2016). 
H3a The impact of URP on firms' innovation commercialisation is moderated by the absorptive capacity.

H3b The impact of URS on firms' innovation commercialisation is moderated by the absorptive capacity.

A second stream of literature underlines that increasing the breadth and depth of external relationships augments the likelihood of innovativeness of a firm (Laursen and Salter, 2006). Accordingly, firms that are more open have a higher chance of considering the knowledge produced by universities as important for their innovation activities (Laursen and Salter, 2004). As search activities are vital for the management literature (Chesbrough, 2006), studies have found that involving a wide number of different types of stakeholders is directly linked to higher innovation performance (Leiponen and Helfat, 2010; Ferraris et al., 2017b). In turn, engaging strongly in knowledge acquisition enables firms in the development of internal knowledge management capabilities (Ahn et al., 2016). In line with this, it is reasonable to infer that firms that have a high level of knowledge acquisition are likely to benefit from ties such as URP and URS, because in such a case firms have higher technological and knowledge management capabilities, useful in collaborating with universities and integrating what university services provide, improving innovation commercialisation.

Following these evidences, we propose the following:

H4a The impact of URP on firms' innovation commercialisation is moderated by knowledge acquisition.

H4b The impact of URS on firms' innovation commercialisation is moderated by knowledge acquisition.

Figure 1 The conceptual model

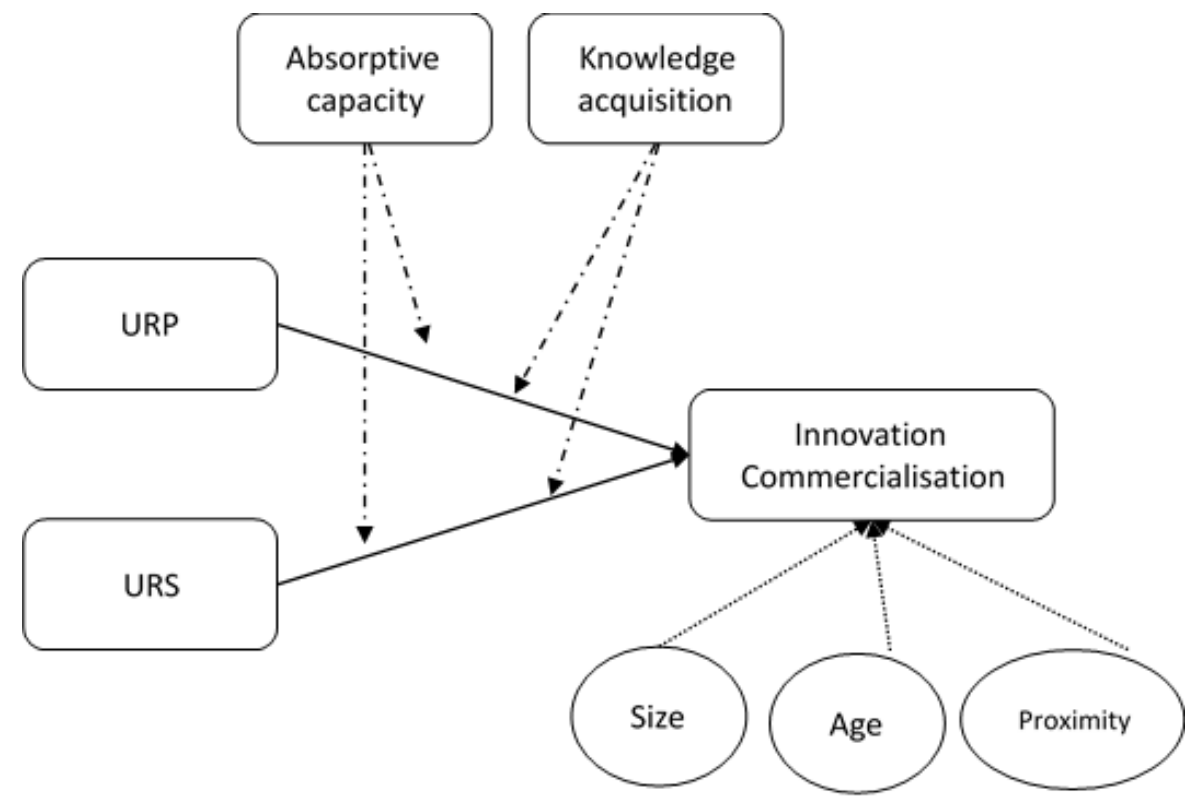




\section{Methodology}

\subsection{Data and research design}

The research is based on a survey methodology, which is useful to enhance the generalisation of results (Dooley, 2001). As a first step, a conceptual model developing hypotheses has been proposed in the previous section. The quantitative study then aims at testing the hypotheses. The empirical research focuses on KIFs located in Italy. We focus on KIFs as they are considered the major providers of technological knowledge in the current knowledge economy, and because this sector is characterised by interorganisational ties and an open approach to innovation. Since literature recognises that it is not easy to establish which firms can be considered 'knowledge intensive', we adopt a perspective that reflects traditional industrial classification schemes, whereby organisations are grouped into industries according to their outputs (Rylander and Peppard, 2005). Our sample includes firms operating in the ICT and electronics sectors according to previous empirical research (Swart and Kinnie, 2003; Bell et al., 2004).

As a first step, we identified 600 KIFs from the Italian database AIDA. Then the CEO and the R\&D managers were emailed with both the questionnaire and a cover letter explaining the purpose of the research. The CEO was deemed appropriate to provide details of the firm's performance measures, while the R\&D managers were particularly relevant in relation to information on the firm's innovation strategy and knowledge acquisition.

All the CEOs and R\&D managers had on average more than ten years of tenure in their firm. This expertise further supports the validity of both informants for reporting data about their organisation. Finally, 185 responses were received (response rate 30.8\%).

The questionnaire, composed of both close and open questions, was developed according to the previously discussed literature and sent with a brief introduction explaining the scope of the research. The first part asked for general information about the firm, such as industry, number of employees, age, and measures of performance. The second part specifically investigated aspects regarding the knowledge acquisition approach and relationships with universities.

The single questions were separated in order to reduce the risk of rationalising the answers of the respondents. In addition, to limit common method variance, dependent and independent variables have been positioned in different positions. In order to test the hypotheses developed, we utilised hierarchical multiple and moderated hierarchical multiple regressions (Cohen, 1983).

\subsection{Dependent and independent variables}

We based our empirical research on several studies on open innovation and innovation management (Laursen and Salter, 2006; Brunswicker and Vanhaverbeke, 2015; Chen et al., 2016) to evaluate firm's innovation commercialisation, our dependent variable. In detail, it is calculated by using the percentage of sales from new or significantly improved products and services compared to total sales of the firm.

URP and URS are two independent variables developed following the literature (Perkmann and Walsh, 2007). For the first variable, we asked participants to indicate: 
a the propensity to formally collaborate with universities

b the extent to which they innovate through R\&D agreements with universities.

For the second variable, we asked participants to indicate:

a the propensity to source knowledge from universities through consultancies

b the extent to which they participate in conferences and academic workshops.

Cronbach's alpha for URP is 0.79 , while Cronbach's alpha for URS is 0.81 , which indicate a good reliability of scales.

Knowledge acquisition captures the extent to which firms engage in sourcing and acquiring knowledge from several counterparts. In the surveys, managers were asked to indicate (using a seven-point Likert-type scale):

a the propensity to look for ideas and innovations outside firms' boundaries

b the intensity of collaboration with each external source

c the propensity to interact with a variety of heterogeneous stakeholders (innovation intermediaries, government agencies, customers, suppliers, competitors and companies operating in other industries).

The average value was used when constructing the variable knowledge acquisition (Cronbach's alpha is 0.72).

Absorptive capacity was built based on previous theoretical studies (Cohen and Levinthal, 1990) developing three scales to measure behaviours and practices for each component of absorptive capacity: $R \& D$ investments, internal knowledge creation and knowledge storage. Each scale was measured on a seven-point Likert-type scale and we used the average value to construct the variable absorptive capacity (Cronbach's alpha is $0.76)$.

\subsection{Control variables}

First, we controlled for the firm size, since it could affect the propensity to engage with universities through formal and informal ties (Mohnen and Hoareau, 2003; Arundel and Geuna, 2004). The number of employees represents the firm size. Also, the firm age, being the number of years since founding, can influence the innovation outcomes (Mazzola et al., 2012).

Geographic proximity to high quality university scientists enhances the firm's ability to capture 'spillovers' of knowledge from the university (Zucker et al., 1998). We measured this through a dummy variable by asking whether, in general, firms cooperate or source knowledge from universities in the same region or other regions $(1=$ same region; $0=$ other regions). 
Table 1 Descriptive analysis

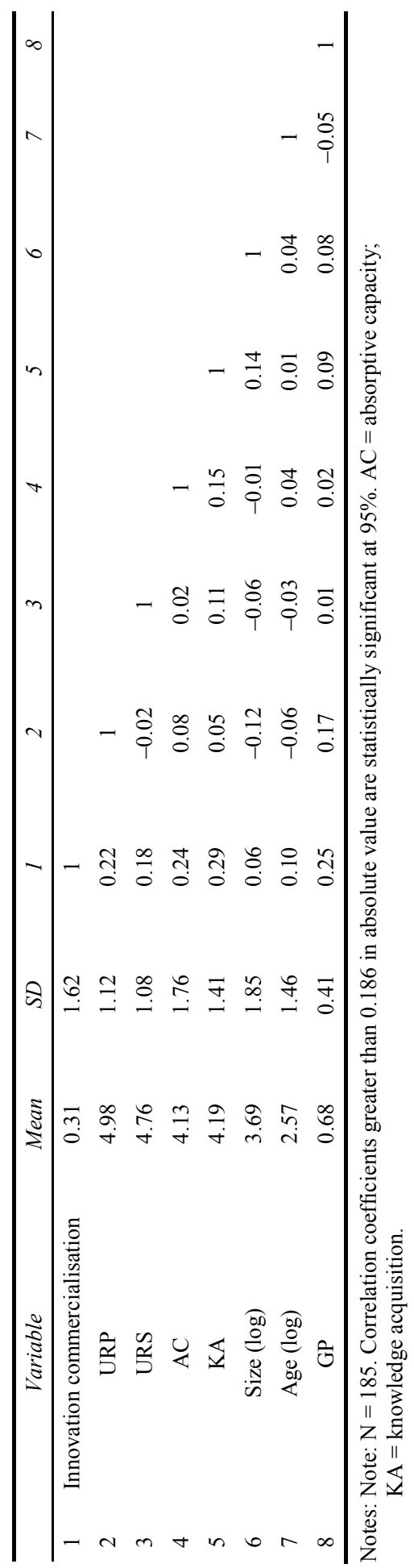


Descriptive analysis of the data provides the main features of the sample, clarifying the weight of each variable (Table 1).

Along with the procedures for testing interaction effects suggested by Aiken and West (1991), the independent variables were standardised before creating the multiplicative terms, thus reducing possible distortion caused by strong correlations between the interaction term and its components.

\section{Results and analysis}

Our hypotheses were tested through OLS regression models and results of our analysis are shown in Table 2. In order to check for multicollinearity, we calculated variance inflation factors (VIFs) for all the variables, which are below the threshold recommended of 10 (Kutner et al., 2004).

Model 1 has an R2 of 0.19 (adjusted R2 is 0.16) and an F-value of $7.41(\mathrm{P}<.01)$. Model 2 has an R2 of 0.29 (adjusted R2 is 0.23 ) and an F-value of $8.28(\mathrm{P}<.001)$. Model 3 has an R2 of 0.42 (adjusted R2 is 0.37 ) and an F-value of $9.76(\mathrm{P}<.001)$. Model 4 has an R2 of 0.38 (adjusted R2 is 0.32$)$ and an F-value of $9.22(\mathrm{P}<.001)$. Model 5 has an R2 of 0.41 (adjusted R2 is 0.36 ) and an F-value of $9.53(\mathrm{P}<.001)$. Model 3 has an R2 of 0.40 (adjusted R2 is 0.35) and an F-value of $8.99(\mathrm{P}<.001)$.

Firm's innovation commercialisation is the dependent variable of each model. Control variables and moderators were entered in Model 1 , which adequately explains a significant amount of the variance ( $\mathrm{R} 2$ adjusted $=0.16, \mathrm{p}<0.01$ ). In the second model, the main effects of URP and URS were entered in order to test H1 and H2. In particular, H1, which proposed a positive relationship between URP and firm's innovation commercialisation, is slightly confirmed $(0.14, \mathrm{p}<0.05)$. In turn, $\mathrm{H} 2$, which proposed a positive relationship between URS and firm's innovation commercialisation, is rejected $(0.12, p>0.05)$. Model 3 and Model 4 assess the moderation effect of absorptive capacity on the relationship between URP and firm's innovation commercialisation, and on the relationship between URS and firm's innovation commercialisation. Both the effects are slightly positive and significant $(0.18 ; \mathrm{p}<0.05$ and $0.14 ; \mathrm{p}<0.05)$; thus $\mathrm{H} 3 \mathrm{a}$ and $\mathrm{H} 3 \mathrm{~b}$ are confirmed.

In model 5 , we entered the interaction term of knowledge acquisition and URP, which is positive and significant $(0.29 ; \mathrm{p}<0.001)$, thus showing a positive moderation effect of knowledge acquisition on the relationship between URP and firm's innovation commercialisation, confirming H4a. Finally, model 6 underlines the moderation effect of knowledge acquisition on the relationship between URS and firm's innovation commercialisation, which is positive and significant $(0.25 ; \mathrm{p}<0.01)$, confirming $\mathrm{H} 4 \mathrm{~b}$.

Finally, it is worth noting that the only control variable whose effect is significant is geographical proximity. This means that acquiring knowledge from and establishing partnerships with universities in the same region is important to increase the results of such collaboration. 
Table 2 Hierarchical regressions predicting firm's innovation commercialisation

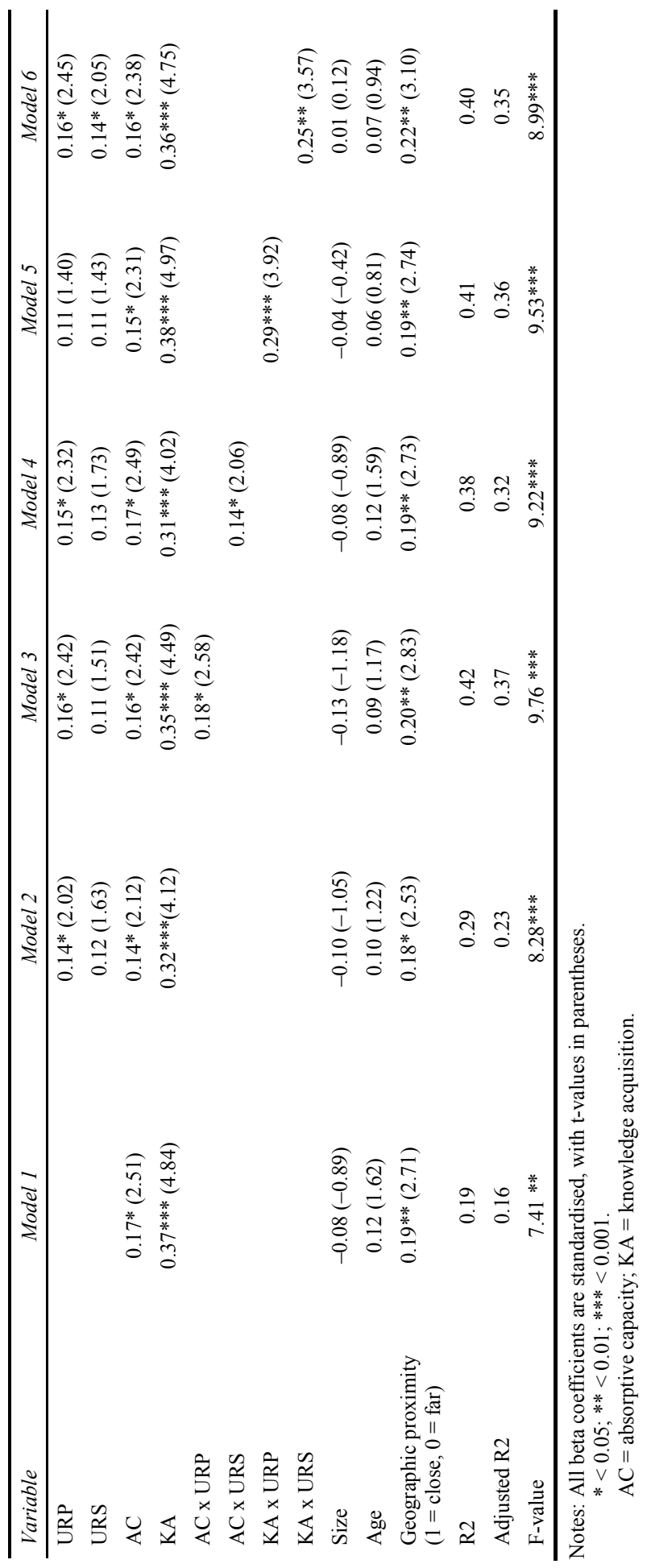




\section{Discussion and conclusions}

The aim of the paper was to investigate firms' knowledge acquisition strategy and its impact on firms' innovation commercialisation, with specific regard to the knowledge and technologies sourced and acquired from universities. In this regard, two types of university-firm links have been considered in the conceptual model of our research, namely URP and URS.

Table 3 Acceptance or rejection of hypotheses

\begin{tabular}{|c|c|c|}
\hline \multicolumn{2}{|c|}{ Hypotheses } & \multirow{2}{*}{$\frac{\text { Accepted/rejected }}{\text { Accepted }}$} \\
\hline H1 & $\begin{array}{l}\text { URP exerts a positive effect on firms' innovation } \\
\text { commercialisation. }\end{array}$ & \\
\hline $\mathrm{H} 2$ & $\begin{array}{l}\text { URS exerts a positive effect on firms' innovation } \\
\text { commercialisation. }\end{array}$ & Rejected \\
\hline $\mathrm{H} 3 \mathrm{a}$ & $\begin{array}{l}\text { The impact of URP on firm's innovation commercialisation is } \\
\text { moderated by the absorptive capacity. }\end{array}$ & Accepted \\
\hline $\mathrm{H} 3 \mathrm{~b}$ & $\begin{array}{l}\text { The impact of URS on firm's innovation commercialisation is } \\
\text { moderated by the absorptive capacity. }\end{array}$ & Accepted \\
\hline $\mathrm{H} 4 \mathrm{a}$ & $\begin{array}{l}\text { The impact of URP on firm's innovation commercialisation is } \\
\text { moderated by the knowledge acquisition. }\end{array}$ & Accepted \\
\hline $\mathrm{H} 4 \mathrm{~b}$ & $\begin{array}{l}\text { The impact of URS on firm's innovation commercialisation is } \\
\text { moderated by the knowledge acquisition. }\end{array}$ & Accepted \\
\hline
\end{tabular}

Six hypotheses have been tested and just one of those has been rejected (Table 3). First of all, our results suggest that URP is more effective than URS in increasing firms' innovation commercialisation. One possible explanation is that a formal partnership can help in exploiting university research knowledge and capabilities in an applied and specific product domain, thus increasing the likelihood of innovation commercialisation (Belderbos et al., 2004; Link and Ruhm, 2009). Then, the moderating role of both absorptive capacity and knowledge acquisition indicate that firms engaged in formal and informal university collaborations could benefit more through higher levels of internal R\&D capabilities and external knowledge (Santoro et al., 2017). In the first case, firms with internal capabilities are able to translate the knowledge provided by universities into products ready for the market (Ferraris et al., 2017a). Strikingly, this result is inconsistent with those of Chen et al. (2016), who found that R\&D capabilities do not lead firms to profit more from collaboration with universities. In turn, an open approach to innovation involving different external sources helps firms to recognise the appropriate university to engage with and the technology/knowledge to be acquired.

In the last years, firms have been approaching open and networked innovation models in order to cope with the current dynamic environment (Scuotto et al., 2017). The increasing numbers of new technological inventions that have emerged from sciencebased actors have called for collaborations between firms and universities. One explanation is that firms face the possibility to explore universities' technology development to increase competitiveness. Moreover, universities often do not have the managerial capabilities to commercialise their inventions. Technologies that do not enter the market limit societal growth and the economic return of the investments (Ardito et al., 2015). In line with this, the results of university research are more and more deemed to create relevant market opportunities and play a key role in national innovation processes. 
In this context, the commercialisation of university technological inventions has been identified as an effective path for the introduction of breakthrough innovations in society, hence underlining a shift in the role of universities from education providers to scientific knowledge and technology producers in the current knowledge-driven economy (Etzkowitz and Leydesdorff, 2000; Del Giudice et al., 2013).

Findings of this paper help us to put forward several implications to theory. Firstly, the paper furthers our understanding of the university-firm partnership, long neglected in the open innovation field. In this case, the paper suggests that simply sourcing knowledge or technologies from university is not enough to commercialise innovation. Firms have to develop internal capabilities and include other external sources for a better knowledge recombination. In this regard, absorbing new knowledge and technologies from universities and increasing the capacity to use that knowledge properly is critical for firms.

Secondly, the paper underlines the different roles of URP and URS in the universityfirm collaboration domain, highlighting that, for firms with a specific innovation commercialisation project, the formal tie with universities is a more effective strategy.

Thirdly, the research confirms the importance of geographical proximity when establishing partnerships with universities.

This paper provides managers of KIFs with some interesting practical implications. Firstly, formal and structured partnerships with universities are strongly recommended to foster innovation. In this regard, rather than sourcing knowledge informally, established partnerships can provide explicit knowledge about solutions and technologies ready to be applied to new products. Secondly, and most importantly, partnerships with universities require firms to develop capabilities related to the absorption and integration of knowledge. Accordingly, it is suggested that managers increase investments in internal R\&D and efforts in knowledge acquisition to benefit from structured and steady partnerships with universities aimed to innovate. In this way, the knowledge base of the firm increases and allows to seek the right partners and to develop joint projects with universities.

This study has several limitations that provide directions for future research. Firstly, this research is limited to the sampling frame of KIFs in Italy. Empirical studies focusing on a single industry are likely to present homogenous results and are therefore appropriate for testing the above relationships. However, this method could reduce and limit the generalisability of the findings. Therefore, it could be interesting in the future to analyse the university-firm relationship in other industries and countries. Secondly, our research did not investigate the role of the type and nature of the knowledge acquired, which often can be different. Future studies may capture these characteristics considering the type of knowledge acquired.

\section{References}

Ahn, J.M., Ju, Y., Moon, T.H., Minshall, T., Probert, D., Sohn, S.Y. and Mortara, L. (2016) 'Beyond absorptive capacity in open innovation process: the relationships between openness, capacities and firm performance', Technology Analysis \& Strategic Management, Vol. 28, No. 9, pp.1009-1028.

Aiken, L. and West, S. (1991) Multiple Regression: Testing and Interpreting Interactions, Sage, Newburg Park, CA. 
Anselin, L., Varga, A. and Acs, Z. (1997) 'Local geographic spillovers between university research and high technology innovations', Journal of Urban Economics, Vol. 42, No. 3, pp.422-448.

Ardito, L., Messeni Petruzzelli, A. and Albino, V. (2015) 'From technological inventions to new products: a systematic review and research agenda of the main enabling factors', European Management Review, Vol. 12, No. 3, pp.113-147.

Arundel, A. and Geuna, A. (2004) 'Proximity and the use of public science by innovative European firms', Economics of Innovation and new Technology, Vol. 13, No. 6, pp.559-580.

Arvanitis, S., Kubli, U. and Woerter, M. (2008) 'University-industry knowledge and technology transfer in Switzerland: what university scientists think about co-operation with private enterprises', Research Policy, Vol. 37, No. 10, pp.1865-1883.

Arvanitis, S., Sydow, N. and Wörter, M. (2005) Is there any Impact of University-Industry Knowledge Transfer on the Performance of Private Enterprises? An Empirical Analysis based on Swiss Firm Data, Swiss Institute for Business Cycle Research (KOF) Working Paper, Vol. 117.

Autio, E. and Laamanen, T. (1995) 'Measurement and evaluation of technology transfer: review of technology transfer mechanisms and indicators', International Journal of Technology Management, Vol. 10, Nos. 7-8, pp.643-664.

Beije, P. and Dittrich, K. (2008) 'Developing a research framework for sectoral modes of open innovation', $R \& D$ Management Advanced Workshop 'Integrating Knowledge-Challenges for $R \& D$ Management', Linkoping, Sweden, 15-16 September.

Beise, M. and Stahl, H. (1999) 'Public research and industrial innovations in Germany', Research Policy, Vol. 28, No. 4, pp.397-422.

Belderbos, R., Carree, M. and Lokshin, B. (2004) 'Cooperative R\&D and firm performance', Research Policy, Vol. 33, No. 10, pp.1477-1492.

Bell, J., Crick, D. and Young, S. (2004) 'Small firm internationalization and business strategy: an exploratory study of 'knowledge-intensive' and 'traditional' manufacturing firms in the UK', International Small Business Journal, Vol. 22, No. 1, pp.23-56.

Bercovitz, J.E. and Feldman, M.P. (2007) 'Fishing upstream: firm innovation strategy and university research alliances', Research Policy, Vol. 36, No. 7, pp.930-948.

Bianchi, M., Cavaliere, A., Chiaroni, D., Frattini, F. and Chiesa, V. (2011) 'Organisational modes for open innovation in the bio-pharmaceutical industry: an exploratory analysis', Technovation, Vol. 31, No. 1, pp.22-33.

Bloedon, R.V. and Stokes, D.R. (1994) 'Making university/industry collaborative research succeed', Research-Technology Management, Vol. 37, No. 2, pp.44-48.

Branstetter, L. and Ogura, Y. (2005) Is Academic Science driving a Surge in Industrial Innovation? Evidence from Patent Citations, No. w11561, National Bureau of Economic Research.

Bresciani, S., Ferraris, A. and Del Giudice, M. (2017) 'The management of organizational ambidexterity through alliances in a new context of analysis: internet of things (IoT) smart city projects', Technological Forecasting and Social Change, Forthcoming.

Bresciani, S., Ferraris, A., Santoro, G. and Nilsen, H.R. (2016) 'Wine sector: companies' performance and green economy as a means of societal marketing', Journal of Promotion Management, Vol. 22, No. 2, pp.251-267.

Bresciani, S., Thrassou, A. and Vrontis, D. (2015) 'Strategic R\&D internationalisation in developing Asian countries-the Italian experience', World Review of Entrepreneurship, Management and Sustainable Development, Vol. 11, Nos. 2-3, pp.200-216.

Brunswicker, S. and Vanhaverbeke, W. (2015) 'Open innovation in small and medium-sized enterprises (SMEs): external knowledge sourcing strategies and internal organizational facilitators', Journal of Small Business Management, Vol. 53, No. 4, pp.1241-1263.

Caloghirou, Y., Kastelli, I. and Tsakanikas, A. (2004) 'Internal capabilities and external knowledge sources: complements or substitutes for innovative performance?', Technovation, Vol. 24, No. 1, pp.29-39. 
Calza, F., Dezi, L., Schiavone, F. and Simoni, M. (2014) 'The intellectual capital of business incubators', Journal of Intellectual Capital, Vol. 15, No. 4, pp.597-610.

Campanella, F., Della Peruta, M.R., Bresciani, S. and Dezi, L. (2017) 'Quadruple helix and firms' performance: an empirical verification in Europe', The Journal of Technology Transfer, Vol. 42, No. 2, pp.267-284.

Carayannis, E.G. (1998) 'The strategic management of technological learning in project/program management: the role of extranets, intranets and intelligent agents in knowledge generation, diffusion, and leveraging', Technovation, Vol. 18, No. 11, pp.697-703.

Carayannis, E.G. and Laget, P. (2004) 'Transatlantic innovation infrastructure networks: public-private, EU-US R\&D partnerships', $R \& D$ Management, Vol. 34, No. 1, pp.17-31.

Chandler, A.D. (1990) Strategy and Structure: Chapters in the History of the Industrial Enterprise, Vol. 120, MIT Press, Cambridge, MA: MIT Press.

Chen, Y., Vanhaverbeke, W. and Du, J. (2016) 'The interaction between internal R\&D and different types of external knowledge sourcing: an empirical study of Chinese innovative firms', $R \& D$ Management, Vol. 46, No. S3, pp.1006-1023.

Chesbrough, H. and Prencipe, A. (2008) 'Networks of innovation and modularity: a dynamic perspective', International Journal of Technology Management, Vol. 42, No. 4, pp.414-425.

Chesbrough, H., Vanhaverbeke, W. and West, J. (2006) Open Innovation: Researching a New Paradigm, Oxford University Press on Demand, Oxford.

Chesbrough, H.W. (2006) Open Innovation: The New Imperative for Creating and Profiting from Technology, Harvard Business Press, Boston, MA.

Cockburn, I.M. and Henderson, R.M. (1998) 'Absorptive capacity, coauthoring behavior, and the organization of research in drug discovery', The Journal of Industrial Economics, Vol. 46, No. 2, pp.157-182.

Cockburn, I.M., Henderson, R.M. and Stern, S. (2000) 'Untangling the origins of competitive advantage', Strategic Management Journal, Vol. 21, Nos. 10-11, pp.1123.

Cohen, J. (1983) 'The cost of dichotomization', Applied Psychological Measurement, Vol. 7, No. 3, pp.249-253.

Cohen, W.M. and Levinthal, D.A. (1990) 'Absorptive capacity: a new perspective on learning and innovation', Administrative Science Quarterly, Vol. 35, No. 1, pp.128-152.

Cohen, W.M., Florida, R., Randazzese, L. and Walsh, J. (1998) 'Industry and the academy: uneasy partners in the cause of technological advance', in Noll, R. (Ed.): Challenges to the University, Brookings Institution Press, Washington, DC.

Cohen, W.M., Nelson, R.R. and Walsh, J. (2002) 'Links and impacts: the influence of public research on industrial R\&D', Management Science, Vol. 48, No. 1, pp.1-23.

Cunningham, J.A. and Link, A.N. (2015) 'Fostering university-industry R\&D collaborations in European Union countries', International Entrepreneurship and Management Journal, Vol. 11, No. 4, pp.849-860.

Del Giudice, M. and Della Peruta, M.R. (2016) 'The impact of IT-based knowledge management systems on internal venturing and innovation: a structural equation modeling approach to corporate performance', Journal of Knowledge Management, Vol. 20, No. 3, pp.484-498.

Del Giudice, M. and Maggioni, V. (2014) 'Managerial practices and operative directions of knowledge management within inter-firm networks: a global view', Journal of Knowledge Management, Vol. 18, No. 5, pp.841-846.

Del Giudice, M., Della Peruta, M.R. and Maggioni, V. (2013) 'Collective knowledge and organizational routines within academic communities of practice: an empirical research on science-entrepreneurs', Journal of the Knowledge Economy, Vol. 4, No. 3, pp.260-278.

Dezi, L. (1996) Le dinamiche di convergenza imprenditoriale e settoriale, Risorse immateriali, outsourcing, reti d'impresa, cross border, Cedam, Padova.

Dezi, L. (1996a) Il mercato dell'energia elettrica tra profitto e pubblica utilità, Cedam, Padova. 
Díaz-Díaz, N.L. and de Saá Pérez, P. (2014) 'The interaction between external and internal knowledge sources: an open innovation view', Journal of Knowledge Management, Vol. 18, No. 2, pp.430-446.

Dooley, D. (2001) Social Research Methods, Prentice-Hall, Upper Saddle River, NJ.

Enkel, E. (2010) 'Attributes required for profiting from open innovation in networks', International Journal of Technology Management, Vol. 52, Nos. 3-4, pp.344-371.

Enkel, E. and Gassmann, O. (2010) 'Creative imitation: exploring the case of cross-industry innovation', $R \& D$ Management, Vol. 40, No. 3, pp.256-270.

Enkel, E., Gassmann, O. and Chesbrough, H. (2009) 'Open R\&D and open innovation: exploring the phenomenon', $R \& D$ Management, Vol. 39, No. 4, pp.311-316.

Etzkowitz, H. and Leydesdorff, L. (2000) 'The dynamics of innovation: from national systems and 'Mode 2' to a triple helix of university-industry-government relations', Research Policy, Vol. 29, No. 2, pp.109-123.

Fabrizio, K. (2006) 'The use of university research in firm innovation', in Chesbrough, H., Vanhaverbeke, W. and West, J. (Eds.): Open Innovation: Researching a New Paradigm, pp.134-160, Oxford University Press, Oxford.

Fabrizio, K.R. (2007) 'University patenting and the pace of industrial innovation', Industrial and Corporate Change, Vol. 16, No. 4, pp.505-534.

Ferraris, A., Santoro, G. and Bresciani, S. (2017a) 'Open innovation in multinational companies' subsidiaries: the role of internal and external knowledge', European Journal of International Management, Vol. 11, No. 4, pp.452-468.

Ferraris, A., Santoro, G. and Dezi, L. (2017b) 'How MNC's subsidiaries may improve their innovative performance. The role of external sources and knowledge management capabilities', Journal of Knowledge Management, Vol. 21, No. 3, pp.540-552.

Fontana, R., Geuna, A. and Matt, M. (2003) Firm Size and Openness: The Driving Forces of University-Industry Collaboration, SPRU Electronic Working Paper, SEWP 103, University of Sussex, Brighton, UK.

Fontana, R., Geuna, A. and Matt, M. (2006) 'Factors affecting university-industry R\&D projects: the importance of searching, screening and signalling', Research Policy, Vol. 35, No. 2, pp.309-323.

Gulati, R. (1998) 'Alliances and networks', Strategic Management Journal, Vol. 19, No. 4, pp.293-317.

Hagedoorn, J., Link, A.N. and Vonortas, N.S. (2000) 'Research partnerships', Research Policy, Vol. 29, No. 4, pp.567-586.

Han, J.H. and Heshmati, A. (2016) 'Determinants of financial rewards from industry-university collaboration in South Korea', International Journal of Innovation Management, Vol. 20, No. 7, DOI: 10.1142/S1363919616500754.

Hayton, J.C. and Zahra, S.A. (2005) 'Venture team human capital and absorptive capacity in high technology new ventures', International Journal of Technology Management, Vol. 31, Nos. 3-4, pp.256-274.

Isaksen, A. and Karlsen, J. (2010) 'Different modes of innovation and the challenge of connecting universities and industry: case studies of two regional industries in Norway', European Planning Studies, Vol. 18, No. 12, pp.1993-2008.

Johansson, F. (2004) The Medici Effect: Breakthrough Insights at the Intersection of Ideas, Concepts, and Cultures, Harvard Business Press, Boston, MA.

Katila, R. and Ahuja, G. (2002) 'Something old, something new: a longitudinal study of search behavior and new product introduction', Academy of Management Journal, Vol. 45, No. 6, pp.1183-1194.

Kaufmann, A. and Tödtling, F. (2001) 'Science-industry interaction in the process of innovation: the importance of boundary-crossing between systems', Research Policy, Vol. 30, No. 5, pp.791-804. 
Kim, H. and Park, Y. (2010) 'The effects of open innovation activity on performance of SMEs: the case of Korea', International Journal of Technology Management, Vol. 52, Nos. 3-4, pp.236-256.

Kutner, M.H., Nachtsheim, C. and Neter, J. (2004) Applied Linear Regression Models, McGraw-Hill/Irwin, New York, NY.

Laursen, K. and Salter, A. (2004) 'Searching high and low: what types of firms use universities as a source of innovation?', Research Policy, Vol. 33, No. 8, pp.1201-1215.

Laursen, K. and Salter, A. (2006) 'Open for innovation: the role of openness in explaining innovation performance among UK manufacturing firms', Strategic Management Journal, Vol. 27, No. 2, pp.131-150.

Lee, Y.S. (2000) 'The sustainability of university-industry research collaboration: an empirical assessment', The Journal of Technology Transfer, Vol. 25, No. 2, pp.111-133.

Leiponen, A. and Helfat, C.E. (2010) 'Innovation objectives, knowledge sources, and the benefits of breadth', Strategic Management Journal, Vol. 31, No. 2, pp.224-236.

Leyden, D.P. and Link, A.N. (2013) 'Knowledge spillovers, collective entrepreneurship, and economic growth: the role of universities', Small Business Economics, Vol. 41, No. 4, pp.797-817.

Link, A.N. and Rees, J. (1990) 'Firm size, university based research, and the returns to R\&D', Small Business Economics, Vol. 2, No. 1, pp.25-31.

Link, A.N. and Ruhm, C.J. (2009) 'Bringing science to market: commercializing from NIH SBIR awards', Economics of Innovation and New Technology, Vol. 18, No. 4, pp.381-402.

Link, A.N., Hall, B.H. and Scott, J.T. (2003) 'Universities as research partners', Review of Economics and Statistics, Vol. 85, No. 2, pp.485-491.

Mazzola, E., Bruccoleri, M. and Perrone, G. (2012) 'The effect of inbound, outbound and coupled innovation on performance', International Journal of Innovation Management, Vol. 16, No. 6, pp.1-27.

Medda, G., Piga, C. and Siegel, D.S. (2005) 'University R\&D and firm productivity: evidence from Italy', Journal of Technology Transfer, Vol. 30, Nos. 1-2, pp.199-205.

Meyer-Krahmer, F. and Schmoch, U. (1998) 'Science-based technologies: university-industry interactions in four fields', Research Policy, Vol. 27, No. 8, pp.835-851.

Mohnen, P. and Hoareau, C. (2003) 'What type of enterprise forges close links with universities and government labs? Evidence from CIS 2', Managerial and Decision Economics, Vol. 24, Nos. 2-3, pp.133-145.

Myoken, Y. (2010) 'Demand-orientated policy on leading-edge industry and technology: public procurement for innovation', International Journal of Technology Management, Vol. 49, Nos. 1-3, pp.196-219.

Narin, F., Hamilton, K.S. and Olivastro, D. (1997) 'The increasing linkage between US technology and public science', Research Policy, Vol. 26 No. 3, pp.317-330.

Perkmann, M. and Walsh, K. (2007) 'University-industry relationships and open innovation: towards a research agenda', International Journal of Management Reviews, Vol. 9, No. 4, pp.259-280.

Romano, M., Del Giudice, M. and Nicotra, M. (2014) 'Knowledge creation and exploitation in Italian universities: the role of internal policies for patent activity', Journal of Knowledge Management, Vol. 18, No. 5, pp.952-970.

Rylander, A. and Peppard, J. (2005) 'What really is a knowledge-intensive firm?', Royal Institute of Technology, pp.1-28.

Salter, A.J. and Martin, B.R. (2001) 'The economic benefits of publicly funded basic research: a critical review', Research Policy, Vol. 30, No. 3, pp.509-532.

Sampson, R.C. (2007) 'R\&D alliances and firm performance: the impact of technological diversity and alliance organization on innovation', Academy of Management Journal, Vol. 50 No. 2, pp.364-386. 
Santoro, G., Ferraris, A., Giacosa, E. and Giovando, G. (2016) 'How SMEs engage in open innovation: a survey', Journal of the Knowledge Economy, pp.1-14, DOI: https://doi.org/ 10.1007/s13132-015-0350-8.

Santoro, G., Vrontis, D., Thrassou, A. and Dezi, L. (2017) 'The Internet of Things: building a knowledge management system for open innovation and knowledge management capacity', Technological Forecasting and Social Change, Forthcoming.

Santoro, M.D. and Chakrabarti, A.K. (2002) 'Firm size and technology centrality in industry-university interactions', Research Policy, Vol. 31, No. 7, pp.1163-1180.

Scuotto, V., Ferraris, A. and Bresciani, S. (2016) 'Internet of Things: applications and challenges in smart cities: a case study of IBM smart city projects', Business Process Management Journal, Vol. 22, No. 2, pp.357-367.

Scuotto, V., Santoro, G., Bresciani, S. and Del Giudice, M. (2017) 'Shifting intra-and inter-organizational innovation processes towards digital business: an empirical analysis of SMEs', Creativity and Innovation Management, Vol. 26, No. 3, pp.247-255.

Segarra-Blasco, A. and Arauzo-Carod, J.M. (2008) 'Sources of innovation and industry-university interaction: evidence from Spanish firms', Research Policy, Vol. 37, No. 8, pp.1283-1295.

Siegel, D.S., Waldman, D.A., Atwater, L.E. and Link, A.N. (2003) 'Commercial knowledge transfers from universities to firms: improving the effectiveness of university-industry collaboration', The Journal of High Technology Management Research, Vol. 14, No. 1, pp.111-133.

Swart, J. and Kinnie, N. (2003) 'Sharing knowledge in knowledge-intensive firms', Human Resource Management Journal, Vol. 13, No. 2, pp.60-75.

Teece, D.J. (1986) 'Profiting from technological innovation: implications for integration, collaboration, licensing and public policy', Research Policy, Vol. 15, No. 6, 285-305.

Tidd, J. and Trewhella, M.J. (1997) 'Organizational and technological antecedents for knowledge acquisition and learning', $R \& D$ Management, Vol. 27, No. 4, 359-375.

Van De Vrande, V., Vanhaverbeke, W. and Gassmann, O. (2010) 'Broadening the scope of open innovation: past research, current state and future directions', International Journal of Technology Management, Vol. 52, Nos. 3-4, pp.221-235.

Van Den Bosch, F.A., Volberda, H.W. and De Boer, M. (1999) 'Coevolution of firm absorptive capacity and knowledge environment: organizational forms and combinative capabilities', Organization Science, Vol. 10, No. 5, pp.551-568.

Vrontis, D., Thrassou, A., Santoro, G. and Papa, A. (2017) 'Ambidexterity, external knowledge and performance in knowledge-intensive firms', The Journal of Technology Transfer, Vol. 42, No. 2, pp.374-388.

West, J. and Bogers, M. (2014) 'Leveraging external sources of innovation: a review of research on open innovation', Journal of Product Innovation Management, Vol. 31, No. 4, pp.814-831.

Zahra, S.A. and George, G. (2002) 'Absorptive capacity: a review, reconceptualization, and extension’, Academy of Management Review, Vol. 27, No. 2, pp.185-203.

Zucker, L.G., Darby, M.R. and Brewer, M.B. (1998) 'Intellectual human capital and the birth of U.S. biotechnology enterprises’, American Economic Review, Vol. 88, No. 1, 290-306. 